Sitzungsberichte

der Akademie der Wissenschaften der DDR

\title{
Peter Oehme
}

\section{Aktuelle Probleme der Peptidforschung}


